\title{
Diet of the marsh deer in the Paraná River Delta, Argentina-a vulnerable species in an intensive forestry landscape
}

\author{
Violeta C. Marin ${ }^{1}$ (1) V Vanina A. Fernández ${ }^{1} \cdot$ María Ana Dacar $^{2,3} \cdot$ Diego G. Gutiérrez $^{2,4,5} \cdot$ Darío Fergnani $^{1,2}$. \\ Javier A. Pereira ${ }^{1,2}$
}

Received: 7 May 2019 / Revised: 24 December 2019 / Accepted: 30 December 2019 / Published online: 9 January 2020

(C) Springer-Verlag GmbH Germany, part of Springer Nature 2020

\begin{abstract}
The marsh deer (Blastocerus dichotomus) is the largest deer native to South America, occurring in wetlands and marshy habitats. The southernmost population of the species is found in the Paraná River Delta, Argentina, in a wetland system highly modified by intensive forestry activity. Foresters perceive high levels of economic losses attributed to deer herbivory which drives marsh deer poaching. We carried out the first study of the dietary composition of the marsh deer in this wetland by using microhistological analysis of feces collected seasonally. Seventy-three food items were identified in the marsh deer diet, but only eight had frequencies of $>3 \%$ in the annual diet. Macrophytes dominated the diet throughout the year (seasonal percent frequencies 31$42 \%$ ) due to the high occurrence of Ludwigia bonariensis (24\% of average seasonal frequency). Trees, vines, forbs, and shrubs contributed less frequently to the diet, while grasses and grass-like plants were marginally represented (i.e., $<2 \%$ ). Exotic plant species comprised 38\% of the annual diet, and tree species of commercial importance (Salix sp. and Populus R22) were poorly represented $(\leq 5.5 \%$ per season). The marsh deer in this wetland could be categorized as a browser, differing from the feeding behavior reported for the species in the Brazilian Pantanal (grazer-browser) and suggesting a trophic elasticity in this cervid. Since commercial tree species comprised a very small portion of the diet of this deer, a change in producers' perception toward the species is needed to diminish this conflict, and our data are important to develop context-specific conservation and management solutions.
\end{abstract}

Keywords Blastocerus dichotomus $\cdot$ Exotic species $\cdot$ Forestry plantations $\cdot$ Human-wildlife conflict $\cdot$ Wetland

Violeta C. Marin

mviolec@gmail.com

1 División Mastozoología, Museo Argentino de Ciencias Naturales "Bernardino Rivadavia", Av. Ángel Gallardo 470, CP C1405DJR Buenos Aires, Argentina

2 Consejo Nacional de Investigaciones Científicas y Técnicas (CONICET), Buenos Aires, Argentina

3 Grupo de Investigaciones de la Biodiversidad (GIB), Instituto Argentino de Investigaciones de Zonas Áridas (IADIZA), CCT Mendoza-CONICET, Av. Ruiz Leal s/n, Parque General San Martín, CC 507, CP 5500 Mendoza, Argentina

4 División Plantas Vasculares, Museo Argentino de Ciencias Naturales "Bernardino Rivadavia", Av. Ángel Gallardo 470, CP C1405DJR Buenos Aires, Argentina

5 Laboratorio de Morfología Comparada de Espermatófitas (LAMCE), FCAyF, UNLP, Av. 60 s/n, between 116 and 118, CP $1900 \mathrm{La}$ Plata, Argentina

\section{Introduction}

Conserving wildlife in human-dominated landscapes requires addressing several forms of human-wildlife conflict (or, actually, the conflict between conservation and other human activities; Redpath et al. 2015). As an example, crop damage by herbivores may trigger responses by agricultural producers (i.e., lethal control or other management actions), and this interaction can affect both the sustainability of the economic activity and the conservation of the species involved (Conover 2001). The perceived costs of such damages by agricultural producers (e.g., financial losses) do not always match with the actual costs (e.g., Naughton-Treves 1997; Siex and Struhsaker 1999; Hill 2004), presenting a dilemma for wildlife managers facing the demands of people regarding control of problem animals. Thus, the appropriate management of conflicts could be benefited from increased ecological knowledge to accurately assess human-wildlife interactions, which is imperative if the target species or population is of conservation concern. 
The marsh deer (Blastocerus dichotomus) is the largest (up to $140 \mathrm{~kg}$ ) native deer in South America, occurring in flooded grasslands, vegetated lagoons, and swamps with floating marshes (Pinder and Grosse 1991; Piovezan et al. 2010). Historically, the species occupied a wide range of habitats along the major river basins (Weber and González 2003), but is now restricted to fragmented populations from central Brazil and southeastern Peru to east-central Argentina. Poaching, habitat loss, and diseases are the main threats to this species, currently categorized as vulnerable by the IUCN (Duarte et al. 2016).

The southernmost population of the marsh deer is found in the lower Paraná River Delta in Argentina (Varela 2003). Onethird of the freshwater marshes of the lower Delta $\left(1630 \mathrm{~km}^{2}\right)$ has been replaced by pastures and forestry since the beginning of the twenty-first century (Sica et al. 2016). Marsh deer seems to have adapted to this drastic change in the habitat physiognomy, and its current presence in this wetland is mostly linked to landscapes under forestry production (Varela 2003; Pereira et al. 2018). Although local forestry producers usually report damage (i.e., browsing, fraying caused by antler rubbing) to commercial trees by deer, only a minor fraction of these producers perceive high levels of damage and economic losses and support marsh deer poaching as a management option (Iezzi et al. 2018). Perceptions of these radical producers are based on two premises: (1) damages to commercial trees due to deer action are high and widespread in this wetland, and (2) trees of commercial value are important components of the diet of this ungulate. Field surveys partially support the first premise, indicating that damage caused by deer could be more severe than perceived by producers (Iezzi et al. 2018). The second premise, however, cannot be tested because information about the feeding habits of marsh deer in this wetland is lacking.

Quantitative information on the dietary composition of the marsh deer in South America is scarce. In the Iberá wetland in northeastern Argentina (approximately $600 \mathrm{~km}$ north of the lower Paraná River Delta), Beccaceci (1996) found 22 plant species in the diet, mainly herbs and shrubs, and highlighted the importance of macrophytes (i.e., aquatic plants or tolerant to flooding soils) in the diet. In the Brazilian Pantanal (approximately $1700 \mathrm{~km}$ north of the lower Delta), Tomas and Salis (2000) identified 40 plant species in the diet, most of them are macrophytes, while Costa et al. (2006) found 21 plant species in the diet comprising grasses, herbs, shrubs, and trees, including the exotic grass Brachiaria humidicola introduced for cattle forage. These results suggest that the marsh deer mostly fed on leaves of soft, highly digestible, protein-rich plants, and define this species as a grazer-browser strategist (Tomas and Salis 2000). These studies, however, were performed in areas with little human intervention, and consequently may not represent the species' trophic response to change in food availability as has occurred in the lower Paraná River Delta
(Kalesnik and Malvárez 2004; Rossi et al. 2014). Other Neotropical cervid species have shown high flexibility regarding dietary composition, using exotic or cultivated plants (e.g., Eldridge et al. 1987; Richard et al. 1995; Merino et al. 2009).

Attempts to conserve the marsh deer in the lower Paraná River Delta will benefit from understanding the species' interaction with forestry plantations (Pereira et al. 2018), elucidating the importance, or lack thereof, of commercial trees as food for this species. Our objective was to quantify, for the first time, the seasonal composition of the marsh deer's diet in a landscape dominated by forestry plantations in the lower Paraná River Delta. We expect, based on producers' perceptions, the feeding ecology of other Neotropical deer species, and the high availability of exotic plant species in this wetland, that exotic plant species (including trees of commercial importance) would be highly represented in the marsh deer's diet.

\section{Materials and methods}

Study area The lower Paraná River Delta $\left(33^{\circ} 48^{\prime}\right.$ to $34^{\circ} 26^{\prime} \mathrm{S}$, $59^{\circ} 00^{\prime}$ to $58^{\circ} 31^{\prime} \mathrm{W}$; hereafter, "lower Delta") is located in Argentina, at the mouth of the Paraná River and in the upper portion of the Rio de la Plata estuary. This wetland has typical deltaic morphology (numerous islands surrounded by an intricate net of watercourses; Kandus and Malvárez 2004). Climate is warm, with a mean temperature of $22{ }^{\circ} \mathrm{C}$ during the warmest month, and annual precipitation of around $1000 \mathrm{~mm}$ distributed all year round (Servicio Meteorológico Nacional 2015). The original landscape of the lower Delta has been modified since the mid-nineteenth century, mainly due to forestry (Salicaceae; i.e., poplar (Populus spp.), willow (Salix spp.), and wicker (Salix viminalis)), cattle production, and associated practices such as water management (ditches, polders, and levees) aimed to protect pastures and plantations from flooding and to expand productive dry lands (Baigún et al. 2008; Quintana et al. 2014; Sica et al. 2016). Consequently, the original riparian forests of the peripheral levees of the islands have been mostly replaced by commercial plantations of Salicaceae, hamlets, and forestry infrastructure, whereas livestock production has affected vegetative structure and soil properties (Baigún et al. 2008; Quintana et al. 2014). Remnants of secondary forests dominated by exotic vegetation are interspersed in the landscape, with at least 108 exotic plant species found in lower Delta (Kalesnik and Malvárez 2004; Rossi et al. 2014).

Our study was conducted in a sub-region so-called forestry nucleus (f. INTA-Delta del Paraná) within the lower Delta, encompassing ca. $500 \mathrm{~km}^{2}$. This area is approximately $70 \mathrm{~km}$ northeast from the city of Buenos Aires and its conurbation which constitutes one of the most populous metropolitan areas in the America with a population of around 15.6 million. The 
forestry nucleus contains the largest concentration of plantations of poplar and willow of the lower Delta, representing the $60 \%$ of the Argentinean production of Salicaceae (Fracassi et al. 2014). Some producers and forestry companies are diversifying by raising livestock under silvopastoral systems. Native macrophytes such as Scirpus sp., Ludwigia sp., Alternanthera sp., Polygonum sp., and Pontederia sp. are common in watercourses and freshwater marshes of the study area. Exotic plant species with non-commercial use are also widely distributed in the forestry nucleus, including the honeysuckle (Lonicera japonica), iris (Iris pseudacorus), privet (Ligustrum spp.), blackberry (Rubus spp.), white mulberry (Morus alba), and faux indigo (Amorpha fruticosa) (Kalesnik and Malvárez 2004; Rossi et al. 2014).

Study design Plant composition in the marsh deer's diet was analyzed with microhistological analysis of feces (Williams 1969). This non-invasive sampling method has disadvantages (Mc Innis et al. 1983; Alipayo et al. 1992; Olivas et al. 2013), but the visual observation of deer feeding behavior employed in other studies with this species (Beccaceci 1996; Costa et al. 2006 ) is very challenging in this wetland due to the tall vegetation and the rapid flight response of individuals of this population due to human persecution (J. Pereira, pers. obs.).

Nine focal sampling points of 5-10 ha were selected within the study area based on the continuous presence of several individuals of the species (i.e., frequent records of $>2$ marsh deer along the year). Each of these sampling points were visited in fall (late April-May 2015), winter (July 2015), spring (October-November 2015), and summer (January-February 2016), and searched for fresh feces of marsh deer. When fresh feces were found, a sample of up to 10 pellets was collected, stored in plastic bags, and kept at $-18{ }^{\circ} \mathrm{C}$ until processing. Marsh deer fecal pellets were easily distinguishable from pellets of other herbivores occurring in this area (Hydrochoerus hydrochaeris, Myocastor coypus, and cattle). Pellet size and associated footprints were used to discriminate marsh deer's pellets from the exotic axis deer's (Axis axis) pellets, although this species was very rare in the study area.

Overall, 85 composite samples (i.e., samples consisting on a mixture of up to 10 fecal pellets) of marsh deer feces were included in this analysis. Each composite sample was dried on stove at $60{ }^{\circ} \mathrm{C}$ during $24 \mathrm{~h}$ and the microhistological analysis was conducted according to the protocol of Dacar and Giannoni (2001). A microhistological slide was prepared for each composite sample and 50 microscope fields were systematically examined on each slide at $400 \times$, observing epidermal characteristics of leaves (Baumgartner and Martin 1939), roots, and seeds. A reference collection (see below) of histological features of different plant tissues were used to identify food items from the composite samples. Percent composition was determined for each plant species in each composite sample (Holechek and Gross 1982), and composite samples collected from each sampling area within each season were then averaged.

Concurrent with fecal collection, a reference collection of plant species in the forestry nucleus was developed. Collecting effort was concentrated, but not restricted to the nine focal sampling points. At least two complete plants (or parts of a plant for large herbs, vines, shrubs, and trees) were collected from each putative species; one of these specimens was preserved as a voucher and deposited in the herbarium BA (Museo Argentino de Ciencias Naturales "Bernardino Rivadavia") for taxonomic identification. The other sample was dried at $40^{\circ} \mathrm{C}$ and used to develop the reference collection of epidermal patterns. A photographic guide (M. Dacar, unpublished data) of diagnostic characters of each vascular plant recorded at the sampling area was built to assist during microhistological analysis. Each species was categorized based on its origin (native or exotic), plant type (according to the database of Instituto de Botánica Darwinion; http:// www2.darwin.edu.ar/), and local value (commercial or not commercial). In the case of plant types, species and varieties were classified in seven categories in relation to their habit, taxonomy, and/or ecology: (1) macrophytes (shrubs, subshrubs, vines, or herbs - aquatic plants or tolerant to flooding soils); (2) grasses, terrestrial taxa belonging to Poaceae (not aquatic); (3) grass-like plants, terrestrial taxa with morphological and taxonomic relationship to Poaceae (i.e., Cyperaceae); (4) forbs, terrestrial herbaceous taxa belonging to several plant families excepting Poaceae and Cyperaceae; (5) trees, perennial woody plants, typically with a single trunk growing to considerable height and with lateral branches at some distance from the ground; (6) shrubs/subshrubs, perennial woody plants with several main stems arising near the ground, or plants woody only at the base (not aquatic); and (7) vines, climbing plants, usually woody, sometimes herbaceous (not aquatic).

Niche breadth was estimated on a seasonal basis by applying the standardized Levin's index $\left(\mathrm{B}_{\mathrm{A}}\right.$; Hurlbert 1978). In addition, seasonal diet diversity was calculated using the Shannon diversity index (H; Colwell and Futuyma 1971). Associations between seasons and the proportion of macrophytes and exotic plants in the diet (dependent variables) were analyzed with generalized linear mixed models (GLMM) with a binomial error structure and logit link function (Zuur et al. 2009) using the lme4 package (Bates et al. 2015) in R. Since binomial models illustrated overdispersion for both variables (i.e., variance of the data was greater than the predicted by the model; Zuur et al. 2009), we ran beta-binomial models (Harrison 2015) to account for overdispersion using glmmTMB package (Magnusson et al. 2017). A likelihood ratio test (LRT) was used to compare beta-binomial models against the null model (i.e., the model without the fixed factor). The association between seasons and the Shannon diversity index (dependent variable) was examined using an 
ANOVA test. Previously, the normal distribution of residuals and homogeneity of variances were checked by using the Shapiro-Wilks test and Levene test, respectively. In all models, the season was considered as a fixed effect with four levels (fall, winter, spring, and summer) and the sample site was considered as a random effect. All analyses were performed with RStudio version 3.3.3.

\section{Results}

Overall, 49 major food items $(>0.5 \%)$ and 24 trace food items $(<0.5 \%)$ were identified in the marsh deer's annual diet in the lower Delta including 71 plant species from 31 plant families (mostly leaves but also seeds of four species), roots and arthropods (Table 1). The number of food items per season varied from 31 in spring to 50 in summer. Although 15 food items were consistently recorded in the deer's diet across the four seasons, only six of them represented an individual contribution greater than $3 \%$ to the annual diet: two macrophytes (Ludwigia bonariensis and Amorpha fruticosa), one forb (Sida rhombifolia), one shrub (Solanum platense), one vine (Lonicera japonica), and one tree (Morus alba). Another two species (the shrub Rubus ulmifolius and the tree Robinia pseudoacacia) contributed individually with $>3 \%$ to the annual diet, but were not consumed by deer during all seasons. Ludwigia bonariensis ("primrose willow," a macrophyte herb present in tropical and subtropical areas from the southern United States to Central Argentina) had the highest contribution to the annual diet (24.4\%) and to the seasonal diets of fall, winter, and summer (Table 1).

In terms of number of species, forbs (with 23 species) and macrophytes (with 21) contributed the most to the deer's diet (Table 1). By percent occurrence, macrophytes dominated the diet throughout the year, ranging from $31 \%$ in spring to $42 \%$ in winter (Fig. 1). However, seasonal differences in the proportion of macrophytes were not statistically significant (LRT: $\left.\chi^{2}=1.62 ; \mathrm{df}=3 ; P=0.65\right)$. Trees, vines, shrubs/subshrubs, and forbs contributed secondarily to the diet, with seasonal contributions of up to $22 \%$ but never lower than $7 \%$ (Fig. 1). Grasses and grass-like plants were poorly represented (i.e., annual contribution of $<2 \%$ ).

Twenty-one percent of plants ( 15 species) consumed by the marsh deer were exotic. Exotic plants were found in the diet throughout the year, with an average contribution to the annual diet of $38.2 \%$ and seasonally ranging from $24.9 \%$ in fall to $61.6 \%$ in spring which were statistically significant (LRT: $\left.\chi^{2}=12.54 ; \mathrm{df}=3 ; P=0.006\right)$. More frequently occurring exotic species ( $>3 \%$ of the annual diet composition) were the vine Lonicera japonica, the trees Morus alba and Robinia pseudoacacia, the shrub Rubus ulmifolius, and the macrophyte Amorpha fruticosa. Two exotic tree species of commercial importance were found in the marsh deer diet; willow was found in the diet throughout the year, seasonally comprising up to $5.5 \%$, whereas poplar was only represented in the fall diet with a contribution of $0.1 \%$.

Diet diversity $(\mathrm{H})$ varied from 0.51 (fall) to 0.60 (summer), but seasonal differences were not statistically significant (LRT: $\chi^{2}=3.33 ; \mathrm{df}=3 ; P=3.340$ ). For the annual diet, the standardized trophic niche breadth $\left(\mathrm{B}_{\mathrm{A}}\right)$ of the marsh deer was 0.44 with seasonal values ranging from 0.41 to 0.54 , with niche breadth lowest in winter.

\section{Discussion}

The diversity of the diet of marsh deer remained relatively constant throughout the year; however, the diet was more generalist during the summer and fall and more selective during the winter. The marsh deer's diet in the lower Delta was composed predominantly of native plants, with macrophytes as the principle plant group consumed, particularly Ludwigia bonariensis. Exotic plant species were also included in the diet throughout the year, contributing to almost $33 \%$ of the annual diet and comprising $61.6 \%$ of the spring diet. Two exotic plant species, Lonicera japonica and Morus alba, occurred in the diet with a relatively high frequency $(>10 \%)$, while the two tree species of commercial importance occurred in the diet with low frequency $(<6 \%)$.

In contrast to previous studies on the marsh deer diet (Beccaceci 1996; Tomas and Salis 2000; Costa et al. 2006), the landscape composition of our study area had undergone significant changes in land use, being dominated by plantations of Salicaceae and silvopastoral systems, and consequently land management affected the vegetative community and thus wildlife habitat. A well-developed understory in forestry plantations might serve as surrogate habitat for native wildlife, providing food and shelter (Lindenmayer and Hobbs 2004; Simonetti et al. 2013). Large spacing between trees within forestry plantations (low plantation density) increases light penetration to the ground level, permitting for the development of a complex understory (Bull 1981) and in the lower Delta favors a diverse herbaceous layer with a high proportion of forage species, increasing forage for herbivores (Fracassi et al. 2014; Rossi et al. 2014). Within our study area, several plant species that are moderately or highly dominant within plantations, such as Alternanthera philoxeroides, Amorpha fruticosa, Bromus catharticus, Polygonum spp., and Conyza bonariensis (Rossi et al. 2014), were represented in the marsh deer diet. In addition, numerous channels and streams within the lower Delta support a diverse community of macrophytes such as Ludwigia spp., Hydrocotyle bonariensis, and Typha latifolia (Rossi et al. 2014), which comprised an important component of the marsh deer diet.

Also contrarily to previous studies (Beccaceci 1996; Tomas and Salis 2000; Costa et al. 2006), exotic plant species 
Table 1 Diet composition (percent), diet diversity $(\mathrm{H})$, and standardized trophic niche breadth $\left(\mathrm{B}_{\mathrm{A}}\right)$ of the marsh deer (Blastocerus dichotomus) based on microhistological analysis of feces ( $n=85$ composite samples) collected in the lower Paraná River Delta, Argentina, along 2015-2016. Status: Nat (native) and Ex (exotic)

\begin{tabular}{|c|c|c|c|c|c|}
\hline Type of plant/species & Status & $\begin{array}{l}\text { Fall } \\
(n=26)\end{array}$ & $\begin{array}{l}\text { Winter } \\
(n=22)\end{array}$ & $\begin{array}{l}\text { Spring } \\
(n=15)\end{array}$ & $\begin{array}{l}\text { Summer } \\
(n=22)\end{array}$ \\
\hline \multicolumn{6}{|l|}{ Macrophytes } \\
\hline Alternanthera philoxeroides & Nat & 3.5 & 2.3 & 0.1 & 3.6 \\
\hline Amorpha fruticosa & Ex & 0.5 & 3.7 & 8.7 & 1.5 \\
\hline Azolla filiculoides & Nat & - & - & - & 0.5 \\
\hline Echinochloa crus-galli & Nat & 0.5 & 1.5 & - & 0.1 \\
\hline Echinochloa polystachya & Nat & - & 0.5 & - & 0.7 \\
\hline Eclipta prostrata & Nat & 1.6 & 2.4 & 0 & 0.5 \\
\hline Eleocharis montana & Nat & - & - & - & 0.2 \\
\hline Hedychium coronarium & Ex & - & - & 5.5 & - \\
\hline Hydrocotyle bonariensis & Nat & - & 0.3 & 6.0 & - \\
\hline Ludwigia bonariensis & Nat & 35.5 & 26.5 & 7.2 & 28.5 \\
\hline Paspalum urvillei & Nat & - & - & - & 0.6 \\
\hline Typha latifolia & Nat & - & - & 3.7 & 0.1 \\
\hline \multicolumn{6}{|l|}{ Forbs } \\
\hline Calyptocarpus biaristatus & Nat & 5.5 & 3.8 & 1.5 & 0.4 \\
\hline Canna glauca & Nat & 0.5 & - & - & - \\
\hline Capsella bursa-pastoris & Ex & 0.2 & - & 0.5 & - \\
\hline Conyza bonariensis & Nat & 1.3 & 1.5 & 0.3 & 0.1 \\
\hline Duchesnea indica & Ex & - & & 1.3 & 0.9 \\
\hline Equisetum giganteum & Nat & 0.8 & 0.2 & 0.1 & 0.2 \\
\hline Glandularia megapotamica & Nat & 0.1 & 0.5 & - & 0.1 \\
\hline Lepidium didymum & Nat & - & 0.5 & - & - \\
\hline Physalis viscosa & Nat & 0.9 & - & - & 0.2 \\
\hline Polygonum stelligerum & Nat & 1.2 & 0.6 & 2.0 & 0.5 \\
\hline Salvia procurrens & Nat & - & - & 0.1 & - \\
\hline Sida rhombifolia & Nat & 8.9 & 3.5 & 3.9 & 6.7 \\
\hline Solanum chenopodioides & Nat & 0.9 & 3.5 & 2.4 & 1.5 \\
\hline Verbena sp. & & - & - & - & 0.5 \\
\hline \multicolumn{6}{|l|}{ Shrubs/subshrubs } \\
\hline Lantana camara & Nat & 0.5 & - & - & - \\
\hline Pavonia betonicaefolia & Nat & - & 1.7 & 4.8 & - \\
\hline Rubus ulmifolius & Ex & - & - & 7.1 & 5.8 \\
\hline Solanum bonariense & Nat & - & 1.2 & 3.1 & 0.5 \\
\hline Solanum platense & Nat & 8.5 & 5.1 & 1.9 & 0.6 \\
\hline Solanum pseudocapsicum & Nat & 0.8 & 0.4 & - & 0.4 \\
\hline \multicolumn{6}{|l|}{ Vines } \\
\hline Calystegia sepium & Ex & 0.1 & 0.2 & 0.5 & 0.1 \\
\hline Cayaponia bonariensis & Nat & 0.2 & 0.3 & - & 0.5 \\
\hline Cayaponia podantha & Nat & 1.2 & 0.5 & - & 0.9 \\
\hline Cuscuta platyloba & Nat & - & 0.1 & - & 3.0 \\
\hline Leptospron adenantha & Nat & - & 0.2 & 0.5 & 5.0 \\
\hline Leptospron sp. & & - & - & - & 4.6 \\
\hline Lonicera japonica & Ex & 5.9 & 17.5 & 15.3 & 7.3 \\
\hline Mikania micrantha & Nat & - & - & - & 0.5 \\
\hline \multicolumn{6}{|l|}{ Trees } \\
\hline Morus alba & Ex & 15.4 & 9.9 & 8.1 & 9.3 \\
\hline
\end{tabular}


Table 1 (continued)

\begin{tabular}{|c|c|c|c|c|c|}
\hline Type of plant/species & Status & $\begin{array}{l}\text { Fall } \\
(n=26)\end{array}$ & $\begin{array}{l}\text { Winter } \\
(n=22)\end{array}$ & $\begin{array}{l}\text { Spring } \\
(n=15)\end{array}$ & $\begin{array}{l}\text { Summer } \\
(n=22)\end{array}$ \\
\hline Robinia pseudoacacia & Ex & 1.2 & - & 12.4 & 3.1 \\
\hline Salix sp. & Ex & 1.4 & 0.3 & 1.5 & 5.5 \\
\hline \multicolumn{6}{|l|}{ Grasses } \\
\hline Bromus catharticus & Nat & 0.3 & 6.2 & - & - \\
\hline Panicum sp. & & - & - & - & 0.5 \\
\hline \multicolumn{6}{|l|}{ Grass like } \\
\hline Cyperus eragrostis & Nat & - & 1.7 & - & - \\
\hline Rhynchospora corymbosa & Nat & - & 0.9 & - & - \\
\hline Indet. plants & & - & 0.5 & - & 1.5 \\
\hline Roots & & 0.7 & 0.1 & - & 0.2 \\
\hline Arthropods & & 0.7 & 0.6 & 0.4 & 1.2 \\
\hline Trace species & & 1.7 & 1.4 & 1.0 & 2.7 \\
\hline Total no. of food items & & 38 & 40 & 31 & 50 \\
\hline $\mathrm{H}$ & & 0.51 & 0.56 & 0.55 & 0.60 \\
\hline $\mathrm{B}_{\mathrm{A}}$ & & 0.54 & 0.41 & 0.48 & 0.54 \\
\hline
\end{tabular}

constituted an important component (up to $61.6 \%$ during the spring) of the marsh deer diet in the lower Delta. Although native herbivores may be expected to prefer native species as food (Siemann and Rogers 2003; Lankau et al. 2004), exotic species could also provide nutritious forage and be an important or even preferred forage source (e.g., the bulk of the winter diet of dusky-legged guans (Penelope obscura) in the lower Delta was composed of the exotics Ligustrum sinense and L. lucidum (Chinese privets); Merler et al. 2001). Two exotic plant species most consumed by the marsh deer during our study (Lonicera japonica and Morus alba) are suitable forage for herbivores (Sánchez 2002; Ainalis et al. 2006; Rossi et al. 2014) and other cervids exploit these species in areas where they are not native (Sotala and Kirkpatrick 1973; Shah et al. 1983).

Despite their high availability as food sources, commercial tree species were infrequently consumed by the marsh deer despite the leaves of Populus spp. and some varieties of Salix spp. have similar or greater concentration of minerals (e.g., $\mathrm{Ca}, \mathrm{Fe}, \mathrm{Mg}, \mathrm{Zn}$ ) than native forage species of Poaceae and Fabaceae (Rossi et al. 2014). More than 20 different phenolic glycosides have been found in variable concentrations in
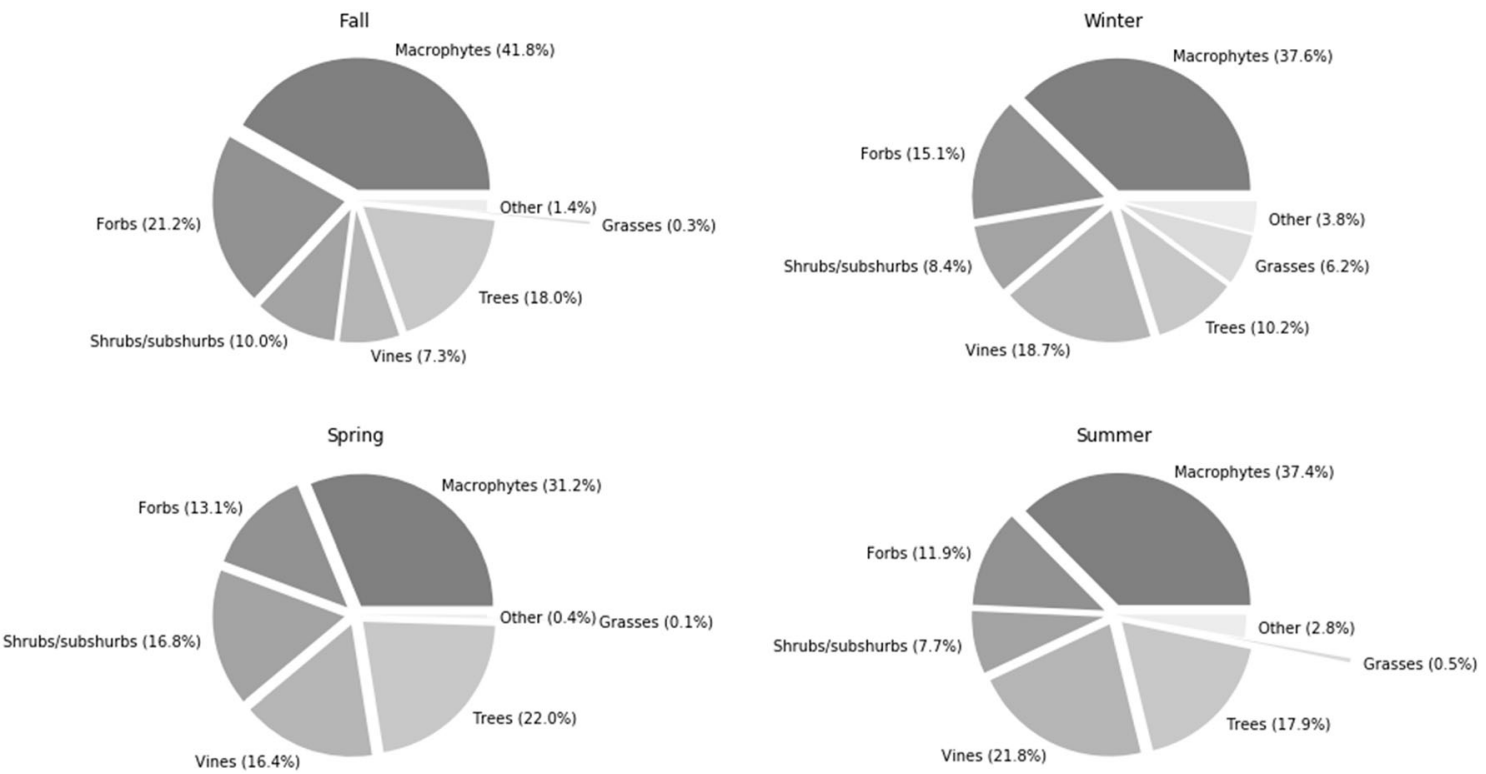

Fig. 1 Pie graphs showing percent composition of plant categories in the marsh deer (Blastocerus dichotomus) diet in the lower Paraná River Delta, Argentina, along 2015-2016. "Other" categories include arthropods, grass like, and indeterminate plants 
Salicaceae which are secondary metabolites that function as feeding deterrents (Boeckler et al. 2011) and consequently may explain the infrequent occurrence of Salicaceae in the marsh deer diet. Supporting this was the absence of Salix nigra in the diet, which is a commonly planted species in our study area with a high content of phenolics and phenolic glycosides (Braccini et al. 2013). This suggests factors other than nutritional quality or availability determine the consumption of willow and poplar species by marsh deer.

Mammalian herbivore foraging behavior can be divided into three groups: grazers (principally grass consumers); browsers (mostly consume plants other than grass); and mixed or intermediate feeders (Hofmann and Stewart 1972). Based on our results, the marsh deer could be categorized as a browser as the contribution of grass to its diet was $<9 \%$. In the Brazilian Pantanal, however, the marsh deer was categorized as a grazer-browser (Tomas and Salis 2000), which suggest that the geographic differences in diet results from trophic elasticity and a response to differences in vegetation and forage availability. Similar geographical variations in food habits were also found between northern (grazers) vs. southern (intermediate feeders) populations of sika deer (Cervus nippon) in the Japanese Archipelago (Ozaki et al. 2007; Takatsuki 2009).

Additionally, mammalian herbivores have been classified into morphophysiological feeding types: concentrate selectors, grass and roughage eaters, and intermediateopportunistic mixed feeders (Hofmann 1985, 1989). Based upon our observations, marsh deer in our study are concentrate selectors, with woody plants (leaves of trees and shrubs), forbs, and vines constituting the bulk of its diet throughout the year and is supported by the digestive system and physiology of the species (Oliveira and Barbanti Duarte 2006) whereby the marsh deer has a high gastro-intestinal transit time classifying it as a concentrate selector. Furthermore, the morphology of the marsh deer's stomach (Machado et al. 2015) indicates that it is a concentrate selector with adaptations to process grasses (the presence of a higher concentration of papillae in the ventral sac of the rumen and its absence in the ruminal pillars, the presence of well-developed ruminal mucosa epithelium, or the presence of a larger number of main cells in the abomasal mucosa). This digestive morphology indicates a special adaptability in the marsh deer and can explain the differences in the marsh deer's dietary composition in the lower Delta and the Brazilian Pantanal, where the species was categorized as an intermediate concentrate selector (Tomas and Salis 2000) due to the high proportion of grasses in its diet.

Deer are herbivores particularly prone to enter into conflict with human, as they frequently cause damage to crops and tree plantations (e.g., Conover 1997; Cote et al. 2004; Ohashi et al. 2014). In the lower Delta, foresters usually report damage to plantations attributable to marsh deer, with browsing on buds and leaves the most commonly reported damage to Salix spp.
(Iezzi et al. 2018). Consequently, foresters consider it necessary to minimize damage from deer to avoid monetary losses with wire fencing, electric fencing, or poaching (Iezzi et al. 2018). We show that commercially important trees comprised an insignificant proportion of the marsh deer diet which indicates that forester's perceptions of damage to plantations by marsh deer are inflated.

Although longer-term and larger-scale research is necessary if our results are representative of the entire delta and interannual variations, our results are important for management applications. To date, our results have been applied by the Argentine Government to improve the rescue protocol for confiscated captive marsh deer. Additionally, we are evaluating on the efficacy of creating small patches of preferred plant species of marsh deer interspersed in or in close proximity to forestry plantations toward providing an alternative food source and reducing herbivory of commercially valuable species.

Management initiatives to mitigate localized damage by deer in plantations are unlikely to diminish this conflict if they are not complemented with a change in foresters' perceptions and attitudes toward marsh deer. Consequently, we are advising local forestry companies to include the marsh deer as a focal species in a forestry certification program, following the standards of the international Forest Stewardship Council (FSC), with the purpose of increasing the value of their production while conserving this threatened species. Through this intervention, we expect to improve the positive image of this species, contributing to increased tolerance by the forestry sector toward marsh deer. Since poaching is the main mortality cause for this species in this wetland (Pereira et al. 2018), our findings provide realistic arguments to offset the persecution of marsh deer based on flawed premises, providing a context-specific solution to diminish this human-wildlife conflict.

Acknowledgments The authors would like to thank the following: $\mathrm{N}$. Fracassi, L. Wolfenson, and E. Villegas for their assistance during fieldwork; EEA INTA - Delta del Parana for logistic support; foresters who granted us access to plantations; M. Stampacchio (MACN-CONICET) for technical assistance for specimens' preparation; and J.J. Thompson for English review of the manuscript. A research permit (Disp. no. 068/16) was provided by Organismo Provincial para el Desarrollo Sostenible (OPDS) of Provincia de Buenos Aires (Argentina). The authors sincerely thank two anonymous reviewers for their suggestions to improve the manuscript.

Funding information The authors also acknowledge the support of the Unidad para el Cambio Rural, Ministerio de Agricultura, Ganadería y Pesca de la Nación (Argentina), for funds to conduct this work under GEF (Global Environmental Facility) 090118 TF.

\section{References}

Ainalis AB, Tsiouvaras CN, Nastis AS (2006) Effect of summer grazing on forage quality of woody and herbaceous species in a silvopastoral system in northern Greece. J Arid Environ 67:90-99 
Alipayo D, Valdez R, Holechek J, Cardenas M (1992) Evaluation of microhistological analysis for determining ruminant diet botanical composition. J Range Manag 45:148-152

Baigún CRM, Puig A, Minotti PG, Kandus P, Quintana RD, Vicari R, Bó RF, Oldani NO, Nestler JA (2008) Resource use in the Parana River Delta (Argentina): moving away from an ecohydrological approach? Ecohydrol Hydrobiol 8:245-262

Bates D, Maechler M, Bolker B, Walker S (2015) Fitting linear mixedeffects models using lme4. J Stat Softw 67:1-48

Baumgartner LL, Martin AC (1939) Plant histology as an aid in squirrel food-habitat studies. J Wildl Manag 3:266-268

Beccaceci MD (1996) Dieta del ciervo de los pantanos, Blastocerus dichotomus, en la reserva del Iberá, Corrientes, Argentina. Mastozool Neotrop 3:193-197

Boeckler GA, Gershenzon J, Unsicker SB (2011) Phenolic glycosides of the Salicaceae and their role as anti-herbivore defenses. Phytochemistry 72:1497-1509

Braccini CL, Vega AS, Chludil HD, Leicach SR, Fernández PC (2013) Host selection, oviposition behaviour and leaf traits in a specialist willow sawfly on species of Salix (Salicaceae). Ecol Entomol 38: 617-626

Bull PC (1981) The consequences for wildlife of expanding New Zealand's forest industry. N Z J For 26:210-231

Colwell RK, Futuyma DJ (1971) On the measurement of niche breadth and overlap. Ecology 52:567-576

Conover MR (1997) Monetary and intangible valuation of deer in the United States. Wildl Soc Bull 25:298-305

Conover MR (2001) Resolving human-wildlife conflicts: the science of wildlife damage management. CRC Press, Boca Raton

Costa SS, Oliveira DB, Manco AM, De Melo GO, Cordeiro JLP, Zaniolo S, Negrelle R, Oliveira LFB (2006) Plants composing the diet of marsh and pampas deer in the Brazilian Pantanal wetland and their ethnomedicinal properties. J Biol Sci 6:840-846

Cote SD, Rooney TP, Tremblay JP, Dussault C, Waller DM (2004) Ecological impacts of deer overabundance. Annu Rev. Ecol Evol Syst 35:113-147

Dacar MA, Giannoni SM (2001) A simple method for preparing references slides of seed. J Range Manag 54:191-193

Duarte JMB, Varela D, Piovezan U, Beccaceci MD Garcia JE (2016) Blastocerus dichotomus. The IUCN Red List of Threatened Species 2016: e.T2828A22160916. https://doi.org/10.2305/IUCN. UK.2016-1.RLTS.T2828A22160916.en. Accessed 08 April 2019

Eldridge WD, MacNamara MM, Pacheco NV (1987) Activity patterns and habitat utilization of pudus (Pudu puda) in south-central Chile. In: Wemmer CM (ed) Biology and management of the Cervidae. Smithsonian Institution Press, Washington, D.C., pp 352-370

Fracassi N., Quintana R.D., Pereira J.A., Mujica G. (2014). Estrategias de Conservación de la Biodiversidad en Plantaciones Forestales de Salicáceas del Bajo Delta del Paraná. INTA, Buenos Aires

Harrison XA (2015) A comparison of observation-level random effect and beta-binomial models for modelling overdispersion in binomial data in ecology \& evolution. PeerJ 3:e1114. https://doi.org/10.7717/ peerj. 1114

Hill CM (2004) Farmers' perspectives of conflict at the wildlifeagriculture boundary: some lessons learned from African subsistence farmers. Hum Dimens Wildl 9:279-286

Hofmann RR (1985) Digestive physiology of the deer - their morphophysiological specialisation and adaptation. In: Drew K, Fennessy P (eds) Biology of deer production. Royal Society New Zealand Bull 22:393-407

Hofmann RR (1989) Evolutionary steps of ecophysiological adaptation and diversification of ruminants: a comparative view of their digestive system. Oecologia 78:443-457

Hofmann RR, Stewart DRM (1972) Grazer or browser: a classification based on the stomach structure and feeding habits of east African ruminants. Mammalia 36:226-240
Holechek JL, Gross BD (1982) Evaluation of different calculation procedures for microhistological analysis. J Range Manag 35:721-723

Hurlbert SH (1978) The measurement of niche overlap and some relatives. Ecology 59:67-77

Iezzi ME, Fracassi NG, Pereira JA (2018) Conservation of the largest cervid of South America: interactions between people and the vulnerable marsh deer Blastocerus dichotomus. Oryx 52:654-660

Kalesnik FA, Malvárez AI (2004) Las especies exóticas invasoras en los sistemas de humedales. El caso del Delta inferior del Río Paraná. Insugeo, Miscelánea 12:131-138

Kandus P, Malvárez AI (2004) Vegetation patterns and change analysis in the lower delta islands of the Paraná River (Argentina). Wetlands 24: $620-632$

Lankau RA, Rogers WE, Siemann E (2004) Constraints on the utilization of the invasive Chinese tallow tree Sapium sebiferum by generalist native herbivores in coastal prairies. Ecol Entomol 29:66-75

Lindenmayer DB, Hobbs RJ (2004) Fauna conservation in Australian plantation forests, a review. Biol Conserv 119:151-168

Machado MRF, Leal LM, Sasahara THC, Oliveira FS, Duarte JMB, Okuda HT (2015) Morfologia do estômago do cervo-do-pantanal (Blastocerus dichotomus, Illiger 1815). Arquivo Brasileiro de Medicina Veterinariae Zootecnia 67:424-432

Magnusson A, Skaug H, Nielsen A, Berg C, Kristensen K, Maechler M, Van Bentham K, Bolker B, Brooks M (2017) Package 'glmmTMB', Generalized Linear Mixed Models using Template Model Builder. https://CRAN.R-project.org/package $=$ glmmTMB

Mc Innis M, Vavra M, Krueger WC (1983) A comparison of four methods used to determine the diets of large herbivores. J Range Manag 36:302-306

Merino ML, Semeñiuk MB, Olocco Diz MJ, Meier D (2009) Utilización de un cultivo de soja por el venado de las pampas (Ozotoceros bezoarticus Linnaeus, 1758), en la provincia de San Luis, Argentina. Mastozool Neotrop 16:347-354

Merler J, Diuk Wasser MA, Quintana RD (2001) Winter diet of duskylegged guan (Penelope obscura) at the Paraná River Delta Region. Stud Neotropical Fauna Environ 36:33-38

Naughton-Treves L (1997) Farming the forest edge: vulnerable places and people around Kibale National Park, Uganda. Geogr Rev 87: 27-46

Ohashi H, Yoshikawa M, Oono K, Tanaka N, Hatase Y, Murakami Y (2014) The impact of sika deer on vegetation in Japan: setting management priorities on a national scale. Environ Manag 54:631-640

Olivas SM, Vital GC, Flores MJ (2013) Métodos para determinar la composición de la dieta en venados: Comparación de su efectividad y factibilidad. Revista Bio Ciencias 2(4):252-260

Oliveira LD, Barbanti Duarte JM (2006) Gastro-intestinal transit time in South American deer. Zoo Biol 25:47-57

Ozaki M, Suwa G, Kaji K, Ohba T, Hosoi E, Koizumi T, Takatsuki S (2007) Correlations between feeding type and mandibular morphology in the sika deer. J Zool 272:244-257

Pereira JA, Fergnani D, Fernández V, Fracassi NG, González V, Lartigau B, Marín V, Tellarini J, Varela D, Wolfenson L (2018) Introducing the "Pantano Project" to conserve the southernmost population of the marsh deer. Deer Specislist Group News (IUCN-SSC-Deer Specislist Group Newsletter) 30:15-21

Pinder L, Grosse AP (1991) Blastocerus dichotomus. Mamm Species 380:1-4

Piovezan U, Tiepolo LM, Tomas WM, Duarte JMB, Varela D, Marinho Filho JS (2010) Marsh deer Blastocerus dichotomus (Illiger, 1815). In: Duarte JMB, González S (eds) Neotropical cervidology: biology and medicine of Latin American deer. Funep/IUCN, Jaboticabal, pp 66-76

Quintana RD, Bó RF, Astrada E, Reeves C (2014) Lineamientos para una Ganadería Ambientalmente Sustentable en el Delta del Paraná. Fundación para la conservación y el uso sustentable de los humedales/Wetlands International LAC, Buenos Aires, Argentina 
Redpath SM, Bhatia S, Young J (2015) Tilting at wildlife: reconsidering human-wildlife conflict. Oryx 49:222-225

Richard E, Juliá JP, Acenolaza P (1995) Hábitos frugívoros de la corzuela parda (Mazama gouzoubira, Fisher, 1824) (Mammalia: Cervidae), en un ambiente secundario de Yungas. Doñana, Acta Vertebrata 22(1-2):19-28

Rossi CA, De Magistris AA, González GL, Carou NE, De Loof EP (2014) Plantas de interés ganadero de la región del bajo delta del Paraná (Argentina). UNLZ, Facultad de Ciencias Agrarias, Buenos Aires

Sánchez MD (2002) Mulberry for animal production. FAO animal production and health paper 147. Food and Agriculture Organization of the United Nations, Rome

Servicio Meteorológico Nacional (2015) Estadística Climatológica. Fuerza Aérea Argentina, Argentina. https:/www.smn.gob.ar/clima/ atlasclimatico. Accessed 08 April 2019

Shah GM, Qadri MY, Yousuf AR (1983) Winter diets of Hangul-deer (Cervus elaphus hanglu Wagner) at Dachigam National Park, Kashmir. J Indian Inst Sci 64:129-136

Sica YV, Quintana RD, Radeloff VC, Gavier-Pizarro GI (2016) Wetland loss due to land use change in the lower Paraná River Delta, Argentina. Sci Total Environ 568:967-978

Siemann E, Rogers WE (2003) Reduced resistance of invasive varieties of the alien tree Sapium sebiferum to a generalist herbivore. Oecologia 135:451-457

Siex KS, Struhsaker TT (1999) Colobus monkeys and coconuts: a study of perceived human-wildlife conflicts. J Appl Ecol 36:1009-1020
Simonetti JA, Grez AA, Estades CF (2013) Providing habitat for native mammals through understory enhancement in forestry plantations. Conserv Biol 27:1117-1121

Sotala DJ, Kirkpatrick CM (1973) Foods of white-tailed deer, Odocoileus virginianus, in Martin County, Indiana. Am Midl Nat 89:281-286

Takatsuki S (2009) Geographical variations in food habits of sika deer: the northern grazer vs. the southern browser. In: McCullough DR, Takatsuki S, Kaji K (eds) Sika deer: biology and management of native and introduced populations. Springer Japan, Tokyo, pp 231237

Tomas WM, Salis SM (2000) Diet of the marsh deer (Blastocerus dichotomus) in the Pantanal wetland, Brazil. Stud Neotropical Fauna Environ 35:165-172

Varela D (2003) Distribución, Abundancia y Conservación del Ciervo de los Pantanos (Blastocerus dichotomus) en el bajo Delta del Río Paraná, Provincia de Buenos Aires, Argentina. BSc thesis. Universidad de Buenos Aires, Buenos Aires, Argentina

Weber M, González S (2003) Latin American deer diversity and conservation: a review of status and distribution. Ecoscience 10:443-454

Williams O (1969) An improved technique for identification of plant fragments in herbivore feces. J Range Manag 22:51-52

Zuur AF, Ieno EN, Walker NJ, Saveliev AA, Smith GM (2009) Mixed effects models and extensions in ecology with R. Springer, New York

Publisher's note Springer Nature remains neutral with regard to jurisdictional claims in published maps and institutional affiliations. 